\title{
CHIEF OF STAFF FINANCE
}

\section{Sgt Ashley C. Lillie*}

\section{The Secretariat}

The fifth Chief of Staff Division, namely Finance, is the end result of seventy years development of the civilian Secretariat established in terms of the Defence Act (Act 13) of 1912.

On 1 July 1912 the Department of Defence was divided into three sections - the civilian Secretariat, the General Staff section and the Administrative section. The Secretariat under the charge of the Under Secretary for Defence, dealt generally with all questions affecting finance and expenditure and the carrying out of the Government's policy in the administration of the Defence Act and the regulations framed thereunder and orders and instructions issued by the Minister. The post of Under Secretary was upgraded to that of Secretary in 1914. In 1922 Sir Roland Bourne, who had served as Secretary since 1912, retired and was succeeded by Brigadier General A.J.E. Brink, Chief of the General Staff since 1920, who was designated 'Chief of the General Staff and Secretary for Defence'. The Financial Under Secretary became the Departmental Accounting Officer.

In 1933 the posts were seperated with Brink remaining Secretary and Sir Pierre (H.A.) van Ryneveld filling the vacant post of Chief of the General Staff. On the retirement of General Brink in 1937 the Secretaryship passed into civilian hands again with his being succeeded by A.H. Broeksma.

Tension between the military and civilian sections of the Department came to the fore under the strains of wartime. Sir Pierre found the situation unacceptable and in 1943 a dispute arose between the Secretary (Brigadier C.H. Blaine) and himself concerning the relationship between the Secretariat and the military sections. The matter was referred to the Minister by the Secretary, but General Smuts felt that war time conditions were unsuitable for final demarcations of responsibility between CGS and the Secretary.

Mr H.F. Cuff who succeeded Brigadier Blaine in 1946 was able to report in 1948 that there had been a marked improvement in the relations

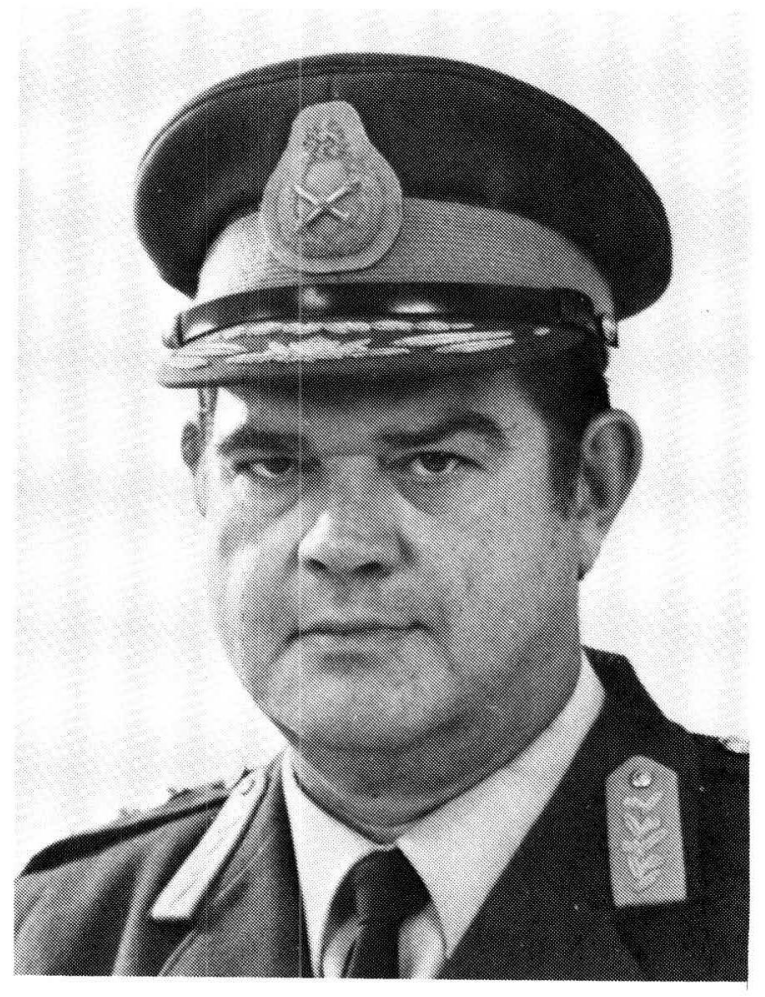

Lt-genl W.J. Bergh, SD, SM Chief of Staff Finance since 17 August 1979

between the Secretariat and military sections. At the same time however, the Secretary referred the question of Departmental control to the Minister who in early 1949 wrote that 'It is seemingly not possible to define the respective responsibilities of the Secretariat and the Military Authorities with exactitude.' The Minister did however go on to list a number of matters as 'the especial responsibilities of the Secretary'. The CGS, Lieutenant General Len Beyers, was not prepared to accept the situation and made certain recommendations which the Secretary in turn could not accept. A committee was appointed to investigate the situation and it recommended that because 'the existing dual arrangement must automatically and unavoidably give rise to delays, diminution of output, duplication of effort, wastage of manpower and, generally, militate against the efficient administration of the Department', the need for the dual organization as it was constituted no longer existed. These recommendations were however not accepted. 


\section{Re-evaluation and reorganization}

As a result of an extensive re-evaluation of the military situation and requirements of South Africa in the early 1960's, considerable modernization and expansion of the country's armed forces was undertaken. With the Department having in effect two horizontal chiefs (the Secretary and the Commandant-General), new organizational problems appeared, including duplication of work and unsatisfactory usage of manpower. On 23 April 1966 the Minister of Defence appointed the Verster Committee to investigate the division of functions in the Department.

After 54 years the Secretariat was disbanded on 16 October 1966 and the Secretary, Mr V.P. Steyn, transferred to another Department. This change was as a result of the report of the Verster Committee which was in favour of abolition of the civilian Secretariat. This recommendation did not however indicate a move towards total militarization, but rather the creation of a civilian organization, within a unified Department of Defence, which would handle most of the functions of the defunct Secretariat.

The Secretariat was replaced by a financial Control Section under a Comptroller, Mr Louis Rive, who had been Deputy Secretary for Defence. The Comptroller was in actual fact responsible for most Secretariat functions. The crux of the problem embodied in the old Secretariat was summed up by Mr Rive when he issued a memorandum discussing the different arguments surrounding the issue. He stated among other things, that history has taught that it is immoral to subject one group to another and in this way deprive it of the right to self-determination; in other words, placing the military man under the authority of a civilian, or vice versa could not work.

\section{Comptroller}

The change to military control of Secretariat functions was only the start of a long process of alteration in the functioning of the SADF. Initially the Comptroller's section was staffed entirely by civilians and was responsible for matters relating to finance, personnel, stores, property, and general administration.

Decentralization as envisaged by the Verster Committee was undertaken, resulting in the delegation of certain responsibilities and duties of the Chief Accountant's office to the Army, Air Force, Navy, Chief of Logistic Services, and Surgeon General. Land and Building matters were integrated with the functions of the Chief of Logistic Services (a short-lived name for Quartermaster-General).

Uncertainty concerning the militarization of the Comptroller's section had presented problems from its inception, the Commandant-General being of the opinion that it was the only way in which an efficient and fully integrated Defence Force could be achieved. The inevitable result of the development of the Comptroller's section was the acceptance of militarization of the section as official policy in 1968.

Mr Rive was transferred to the Department of Posts and Telegraphs to become PostmasterGeneral and on 1 November he was succeeded by Major General E. Pienaar who became the first military Comptroller. At the same time as this change the Directorate of Programming and Budget was transferred to the Comptroller. Militarization affected all sub-sections except Finances (Chief Accountant) and the Defence Stores Inspectorate.

Five Defence Force sections were involved in the reorganization of 1 November 1968, each taking over specific functions of the old Secretariat. They were the Chief of Defence Staff, the Comptroller, the Quartermaster-General, the Chief of Personnel, and the Naval Chief of Staff. The Commandant-General was now permanent head of the Department of Defence as well as Accounting Officer and chief military executive officer.

At the end of 1968 the Comptroller section comprised four sub-sections: the Directorate of Programming and Budget; Finances (Chief Accountant); Stores Administration; and Stores Control (Stores Inspectorate). On 13 May 1969 the subsection Contracts and Claims was transferred to the Comptroller's section and the posts of subsection Finances were converted to military posts at the end of 1969.

On 1 July 1970 the post of Comptroller was upgraded in order to give its holder authority consonant with his status as chief finance officer of the Department and Major General Pienaar was promoted to Lieutenant General. The Chief accountant of the Department, Mr W.J.J. Scholtz, was in turn appointed Deputy Comptroller in his civilian capacity. 
Together with other factors, the unprecedented growth of the Defence Force caused problems of organization and duplication of work within the Comptroller's organization. Part of the solution to the problem lay in total militarization. On 1 April 1972 the post of Deputy Comptroller passed to a military man when Mr Scholtz retired, to be succeeded by Major General J.E. Viljoen.

Total militarization of the old Secretariat was finally achieved on 1 July 1972 when the Stores Inspectorate was militarized and redesignated the Directorate of Internal Audit. In order to distinguish the Comptroller's officers from general administrative service personnel, they were remustered into a new corps, the Finance Service Corps (redesignated the SA Military Finance Service on 1 January 1975) on 1 July 1972.

Internal financial administration was improved on 1 April 1974 when a Directorate of Expenditure Control was established, mainly as a result of the ammendment of the Act in respect of the Defence Special Equipment Account.

The Chief Paymaster was, after many years of deliberation, transferred to the Comptroller's section on 1 January 1975.

The Sections of Director-General, General Administration and the Director-General Management Systems were disbanded towards the end of 1975 and most of their functions were transferred to the Comptroller. On 1 November 1975 when the new organization became effective, three directorates were transferred from the Director-General Management Systems: The Documentation Service, Language Service and Directorate of Electronic Data Processing. From the Director-General, General Administration came the Directorate of Military Museums.

To deal with the enlarged work load, the top administrative structure of the Comptroller's section was re-organized so that there were three General Officers - a Comptroller (Lieutenant General), a Director-General Management (Major General) and a Director-General Finances (Major General). In November 1975 the two Directors-General were redesignated Deputy-Comptroller (Management) and DeputyComptroller (Finance).

\section{Chief of Staff Management Services}

The Comptroller, SADF was redesignated Chief of Staff Management Services on 5 November
1976. Lieutenant General A.J. van Deventer had been appointed to the post on 1 October 1976. The Division was divided into ten directorates, namely Administration, Internal Audit, Military Museums, Documentation Service, Language Service, Financial Co-ordination, Chief Pay Master, Programming and Budget, Electronic Data Processing and Expenditure Control.

\section{Chief of Staff Finance}

With effect from 13 February 1978 Chief of Staff Management Services became Chief of Staff Finance and certain directorates were transferred from the Division. With the exception of the Directorates Documentation Service and Computer Systems, the Division was concerned with purely financial matters.

In May 1978 Chief of Staff Finance consisted of nine directorates, namely Programming and Budget, Financial Co-ordination, Administration, Internal Audit, Chief Pay Master, Documentation Service, Computer Systems, Staff Duties and Financial Information.

The attachment of Lieutenant General van Deventer to the Department of the Prime Minister from 6 August 1979 resulted in the appointment of Major General W.J. Bergh, (now Lieutenant General) as Chief of Staff Finance, a post which he still holds.

During 1979 a re-evaluation of the role of CSF took place, resulting in considerable changes. Directorate Administration was disbanded and a Directorate Financial Information was at the same time included as a section of Directorate Financial Co-ordination which was renamed $\mathrm{Di}$ rectorate Accounts. Probably the most farreaching change was the disbandment of Directorate Staff Duties and the establishment of a Section Staff Duties, directly responsible to CSF. The Directorate Finance Training was established out of the old DSD and included the Finance Training Wing. It was originally intended that the Finance Training Wing be established at SAMS Training Centre; the wing was, however, established at Personnel Services School. In order to achieve more effective personnel utilization and training, the SA Military Finance Service was disbanded in September 1979 and replaced by the Finance Service Corps (Army) and Finance branches in the Air Force, Navy and SAMS. DFSC remained initially at CSF but following the completion of re-organization was transferred to Army $\mathrm{HQ}$. 
Chief of Staff Finance as it currently exists, consists of seven directorates, (Programming and Budget, Accounts, Financial Administration, Internal Audit, Chief Pay Master, Computer Systems and Finance Training) following the transfer of Documentation Service to Chief of Staff Intelligence on 31 December 1981.
* Sgt A.C. Lillie is attached to Sub-section Enquiries at Military Information Bureau and is at present in his second year of study for the $B$ Journ degree at Rhodes University.

\section{Footnotes}

1. In the writing of this article use was made of the same material as that used by Capt R.J. Bouch in his article 'The develooment of the Comptroller's Section, SADF, 1966-1967' which appeared in Militaria 6/3. Files used may not be footnoted in terms of South African archive regulations which prohibit the footnoting of files less than 50 years old. 